\title{
The Similar and Dissimilar TIG Welding of 316L and 321 Austenitic Stainless Steels
}

\author{
Özgür ÇINAR ${ }^{1 *}$, Mehmet Can YARALI ${ }^{1}$, Ertan ERDEMIIR ${ }^{1}$, Burcu Nilgün ÇETINER ${ }^{1}$, Ayhan \\ MERGEN ${ }^{1}$, Arif Nihat GÜLLÜOĞLU ${ }^{1}$ \\ ${ }^{1}$ University of Marmara, Faculty of Engineering, Dept. of Metallurgical and Materials Engineering, \\ 34722, Istanbul, Turkey \\ ozgur.cinar@marmara.edu.tr,
}

\begin{abstract}
Being one the modern high quality industrial welding process especially for stainless steels and titanium alloys. TIG welding process has been has been researched for decades in order to define its parameters such as welding speed, current and arc length to improve the weld penetration. Hence it is a popular technique for joining thin materials - the thickness of the work piece is in general restricted to less than 6 $\mathrm{mm}$ - in manufacturing industries. In this study, AISI 321 and $316 \mathrm{~L}$ stainless steel sheets of $4 \mathrm{~mm}$ of thickness were used as welding metals. Thus, AISI 321 welding metal couples, AISI $316 \mathrm{~L}$ welding metal couples and AISI 321 and 316L welding metal couples were selected to ensure a combination of similar and dissimilar metals. The filler metal rod was made of $316 \mathrm{~L} \mathrm{SS}$. The specimens were cut in dimensions of $150 \times 30 \times 4 \mathrm{~mm}$ as using an abrasive cutter, then the $\mathrm{V}$ weld butt joint configuration with single groove of $37.5^{\circ} \pm 2.5^{\circ}$ groove angle by a lathe machine. The welding current was $200 \mathrm{~A}$ and TIG welding process was performed manually in single under argon shielding gas atmosphere. After TIG welding process, the separate metallographic preparations, then microscopic and macroscopic examinations of the specimens, also hardness measurements of specimens were made. The rest of them was shaped for tensile strength measurement using Instron Universal Testing Machine. The hardness of the specimens were observed being altered in the range of 145-151 HRV (average) and their tensile strength values in the scale of 345$400 \mathrm{MPa}$ (average).
\end{abstract}

Keywords: AISI 321 and 316L Stainless Steels , TIG Welding, Similar and Dissimilar Welding

\section{INTRODUCTION}

Being one the modern high quality industrial welding process especially for stainless steels and titanium alloys. TIG welding process has been has been researched for decades in order to define its parameters such as welding speed, current and arc length to improve the weld penetration [1-3]. While TIG welding offers facile and accurate management of welding parameters, the thickness of the work piece is in general restricted to less than $6 \mathrm{~mm}$ due to the impotency of the welding process such as shallow weld penetration and lower yieldance [4,5]. Hence it is a popular technique for joining thin materials in manufacturing industries. When TIG welding is applied, an arc between a non-consumable tungsten electrode and the work piece is produced under the inert gas shielding the arc, the electrode and the molten pool from the atmosphere contamination [6,7]. The microstructure and its morphology, the tensile strength of the welding 
joint at the heat affected zone during TIG welding can be modified by the welding current due to the heat input through the metal work piece [8,9].

Stainless steels, especially type 300 austenitic stainless steels, have excellent corrosion, good weldability and machinability, also good strength introducing them a material of choice for wide range applications from automotive industry to domestic appliances. Their low carbon percentage is one of the reasons preventing intergranular corrosion. But the compositional heterogeneity owing to the carbide precipitation and sigma phase formation causes hot cracking and significant decrease of the mechanical adequacy in the vicinity of the HAZ[10,11].

Residual stresses and distortions, as results of mismatching and non-uniform distributions of plastic and thermal strains in weldments due to the joint geometry and plate thickness are the limitations to the success of the welded structures, because they may induce crack propagation and intergranular brittle fracture, also when combined with the local degradation, they may conduce to fatigue and stress corrosion cracking, even to reduction in the buckling strength of structures. [12].

This study is aimed to show as a scientific survey the undergraduate thesis work of young engineers, prone to be very dear future researchers in their area, at the same time to determine the material based characteristics affecting the final mechanical properties of the TIG welded zones.

\section{EXPERIMANTAL PROCEDURE}

In this study, AISI 321 and 316L (316L electrode is preferred because of its good corrosion and mechanical properties) stainless steel sheets of $4 \mathrm{~mm}$ of thickness were provided as welding metals. Thus, AISI 316L welding metal couples (Specimens type: T1), AISI 321 welding metal couples (Specimens type: T2) and AISI 321 and 316L welding metal couples (Specimens type: T3) were selected to ensure a combination of similar and dissimilar metals. Austenitic stainless steels grade 316L and 321, with a thickness of $4 \mathrm{~mm}$ and given chemical composition in Table 1 and 2, also as filler rod AISI 316L in Table 3 respectively, were utilized.

Primarily, the specimens were cut in dimensions of $150 \times 30 \times 4 \mathrm{~mm}$ as using an abrasive cutter, then the $\mathrm{V}$ weld butt joint configuration with single groove of $37.5^{\circ} \pm 2.5^{\circ}$ groove angle by a lathe machine. Before welding, the welding plates were ground manually by an abrasive sand paper of 180 grid then cleaned with acetone. TIG welding process was performed manually in single under argon shielding gas atmosphere by undergraduate metallurgical and materials engineering students after taking six months of workshop practice prior their laboratory based scientific studies. The welding parameters are summarized in Table 4. After TIG welding applications, some of the specimens were cut and prepared for metallographic examination. After treatment specimens were cleaned with acetone, mounted, subsequently ground, polished and finally etched by Aqua regia etching solution for about $30 \mathrm{sec}$. The microstructures were observed by optical microscope (Olympus). For macroscopic examination firstly, the welded joint was cold cut from the sample by an abrasive cutter. Then the surface was ground by starting from 240 grid till 1000 grid sand paper and polished using diamond paste of 2 micron. After metallographic preparation, an acid solution comprised of oxalic acid solution ( $10 \mathrm{~g}$ of oxalic acid and $10 \mathrm{cc}$ of distilled water) was disposed and a with a soft clean cloth, wiping over the test piece, After a short time, the parent metal and weld areas were discoloured and their pictures were taken by Sony DSC-W730 digital photographer without zooming. The hardness measurements of the samples were done using FM-ARS 7000 (Future Tech Corp Tokyo, Japan) Full-Automatic Micro hardness Testing System, $100 \mathrm{~g}$ load for $15 \mathrm{~s}$. The rest of them was shaped for tensile strength measurement using Instron Universal Testing Machine with a cross head speed of 5 $\mathrm{mm} / \mathrm{min}$. Tensile tests were carried out with samples according to TS EN ISO 4136. 
Table 1. Composition of AISI 321 stainless steel welding metal (wt \%) [7].

\begin{tabular}{ccccc}
\hline $\mathrm{Fe}$ & $\mathrm{C}$ & $\mathrm{Ni}$ & $\mathrm{Cr}$ & $\mathrm{Mn}$ \\
\hline 68.49 & 0.08 & $9-12.00$ & $17-19.00$ & 2.00 \\
\hline $\mathrm{Ti}$ & $\mathrm{Si}$ & $\mathrm{S}$ & $\mathrm{P}$ & $\mathrm{N}$ \\
\hline 0.70 & 0.75 & 0.03 & 0.045 & 0.10 \\
\hline
\end{tabular}

Table 2. Composition of AISI 316L stainless steel (wt \%) welding metal [8].

\begin{tabular}{cccccccc}
\hline $\mathrm{Fe}$ & $\mathrm{C}$ & $\mathrm{Ni}$ & $\mathrm{Cr}$ & $\mathrm{Mn}$ & $\mathrm{Mo}$ & $\mathrm{Si}$ & $\mathrm{Co}$ \\
\hline 68.49 & 0.029 & 10.02 & 16.67 & 1.65 & 2.05 & 0.37 & 0.21 \\
\hline $\mathrm{Cu}$ & $\mathrm{Nb}$ & $\mathrm{Ti}$ & $\mathrm{V}$ & $\mathrm{W}$ & $\mathrm{Al}$ & $\mathrm{P}$ & $\mathrm{N}$ \\
\hline 0.28 & 0.037 & 0.022 & 0.048 & 0.06 & 0.002 & 0.034 & 0.024 \\
\hline
\end{tabular}

Table 3. Alloying elements' composition of AISI 316L stainless steel (wt \%) filler metal rod [5] (Fe as balance element).

\begin{tabular}{cccc}
\hline $\mathrm{C}$ & $\mathrm{Ni}$ & $\mathrm{Cr}$ & $\mathrm{Mn}$ \\
\hline 0.03 & $10-14.00$ & $16-18.00$ & 2.0 \\
\hline $\mathrm{Mo}$ & $\mathrm{S}$ & $\mathrm{P}$ & $\mathrm{N}$ \\
\hline $2-3.00$ & 0.03 & 0.045 & 0.1 \\
\hline
\end{tabular}

Table 4. TIG welding parameters.

\begin{tabular}{cccc}
\hline $\begin{array}{c}\text { Electrode nominal } \\
\text { diameter }(\mathrm{mm})\end{array}$ & Electrode tip angle $(\mathrm{o})$ & $\begin{array}{c}\text { Filler metal diameter } \\
(\mathrm{mm})\end{array}$ & Welding Current (A) \\
\hline 2.4 & $37.5 \pm 2.5$ & 2.4 & 200 \\
\hline Arc Length $(\mathrm{mm})$ & $\begin{array}{c}\text { Shielding gas flow rate } \\
(\mathrm{L} / \mathrm{min})\end{array}$ & $\begin{array}{c}\text { Backing flow rate } \\
(\mathrm{L} / \mathrm{min})\end{array}$ & $\begin{array}{c}\text { Welding speed } \\
(\mathrm{mm} / \mathrm{min})\end{array}$ \\
\hline 3 & 15 & 10 & 180 \\
\hline
\end{tabular}

The chemical contents of the welding electrodes used in the joining process are shown in tables 5 and 6.

Table 5. Composition of AISI 316L stainless steel (wt \%) [1].

\begin{tabular}{cccccccc}
\hline $\mathrm{Fe}$ & $\mathrm{C}$ & $\mathrm{Ni}$ & $\mathrm{Cr}$ & $\mathrm{Mn}$ & $\mathrm{Mo}$ & $\mathrm{Si}$ & $\mathrm{Co}$ \\
\hline 68.49 & 0.029 & 10.02 & 16.67 & 1.65 & 2.05 & 0.37 & 0.21 \\
\hline $\mathrm{Cu}$ & $\mathrm{Nb}$ & $\mathrm{Ti}$ & $\mathrm{V}$ & $\mathrm{W}$ & $\mathrm{Al}$ & $\mathrm{P}$ & $\mathrm{N}$ \\
\hline 0.28 & 0.037 & 0.022 & 0.048 & 0.06 & 0.002 & 0.034 & 0.024 \\
\hline
\end{tabular}


Table 6. Composition of AISI 304 stainless steel (wt \%) [7].

\begin{tabular}{rcccc}
\hline Fe & $\mathrm{C}$ & $\mathrm{Ni}$ & $\mathrm{Cr}$ & $\mathrm{Mn}$ \\
\hline Balance & 0.05 & 7.84 & 18.07 & 1.537 \\
\hline $\mathbf{C u}$ & $\mathbf{N b}$ & $\mathbf{V}$ & $\mathbf{S i}$ & Mo \\
\hline 0.389 & 0.047 & 0.089 & 0.572 & 0.332 \\
\hline
\end{tabular}

\section{RESULTS AND CONCLUSION}

The overall summary of the welding results are given in Table 7. In Fig. 1 and 2, the microhardness in welding zone and tensile strength values were drawn and shown graphically.

Table 7. Summary of welding conditions and results of mechanical testing.

\begin{tabular}{cccc}
\hline $\begin{array}{c}\text { Specimens/Mechanical } \\
\text { Properties }\end{array}$ & T1 & T2 & T3 \\
\hline $\begin{array}{c}\text { Micro } \\
\text { Hardness (HRV0.1) }\end{array}$ & $145.67 \pm 9.50$ & $146.33 \pm 5.69$ & $151 \pm 11.79$ \\
\hline $\begin{array}{c}\text { Tensile Strenght } \\
(\mathrm{MPa})\end{array}$ & $400 \pm 10$ & $345 \pm 12.03$ & $358 \pm 15.58$ \\
\hline
\end{tabular}

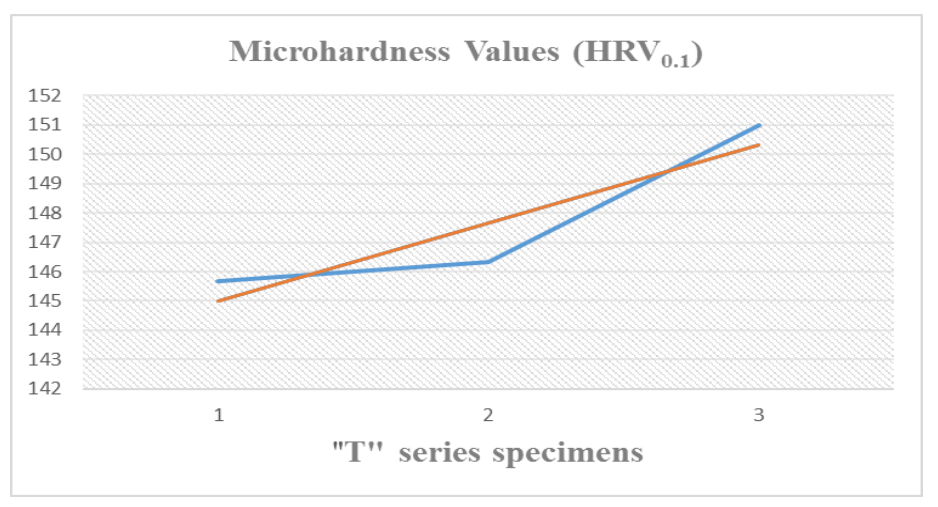

Fig. 1. Comparison of microhardness values of specimen groups (shown as blue line) and tendency curve (shown as orange line) 


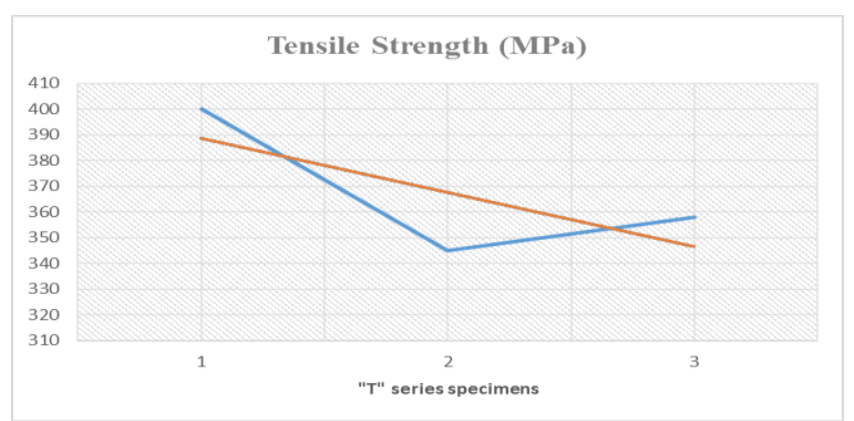

Fig. 2. Comparison of tensile shear force values of specimen groups (shown as blue line) and tendency curve (shown as orange line).

In Fig.3-5, the macroscopic images of of weld beads of TIG welding couples are shown.

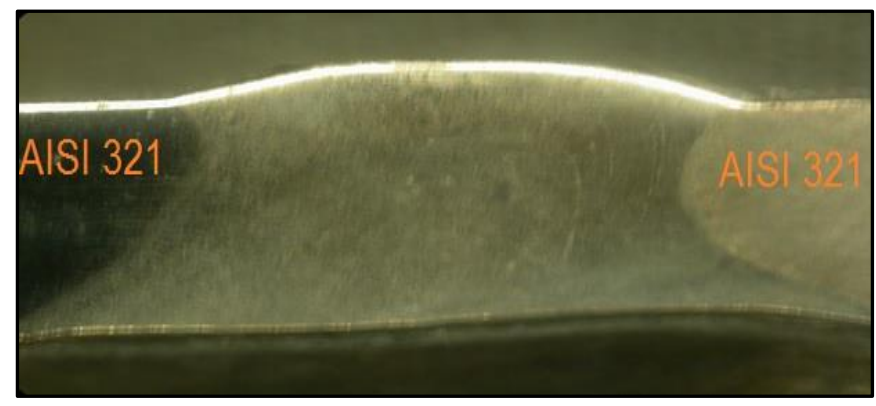

Fig. 3. Macroscopic image of the weld bead, of similar welding of AISI 321 type metal couples base and weld metals- .

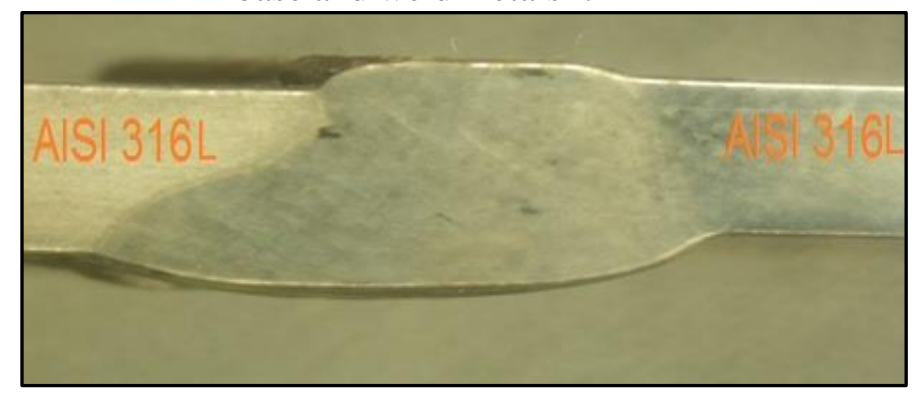

Fig. 4. Macroscopic image of the weld bead, of similar welding of AISI 316L type metal couples base and weld metals.

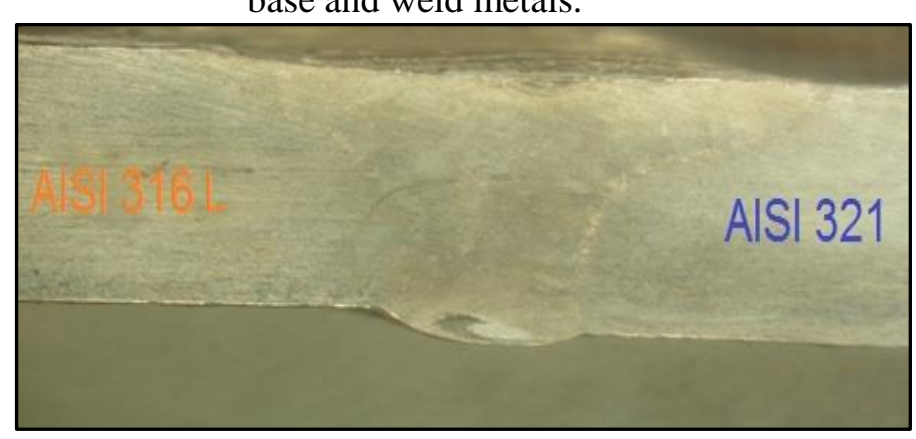

Fig. 5. Macroscopic images of the weld bead, of dissimilar welding of AISI 316L and 321 type metal couples -base and weld metals. 
In Fig.6-8, the the microscopic images of of weld beads of TIG welding couples are shown.

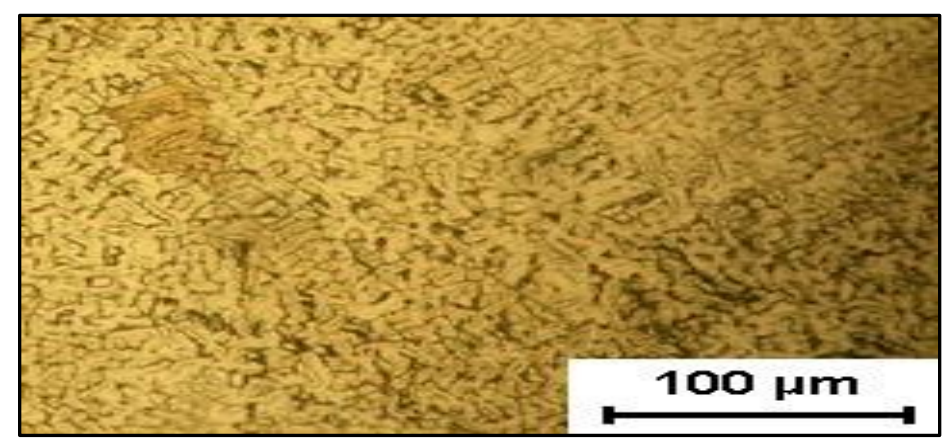

Fig. 6. The weld bead,of similar welding of AISI 321 type metal couples -base and weld metals(Magnification 5x).

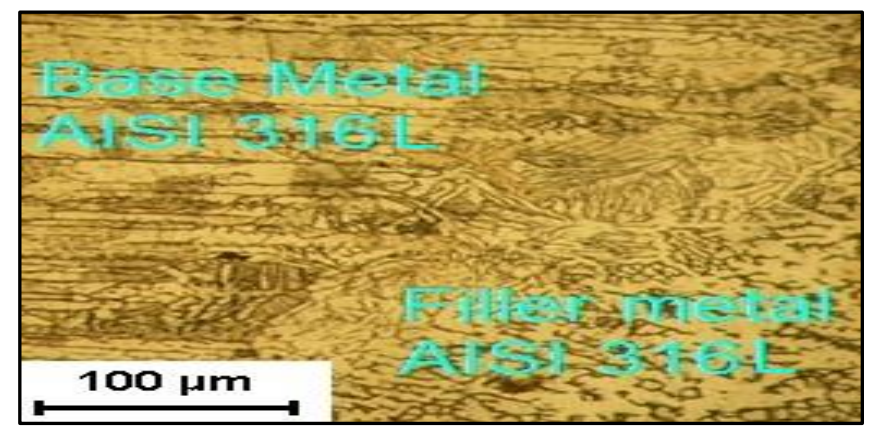

Fig. 7. The weld bead,of similar welding of AISI 316L type metal couples -base and weld metals(Magnification 5x).

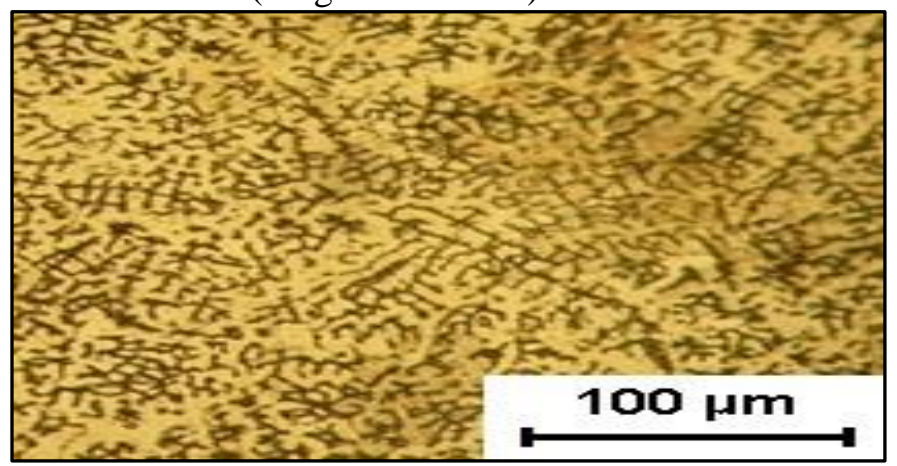

Fig. 8. The weld bead,of dissimilar welding of AISI 316L and 321 type metal couples -base and weld metals- (Magnification 5x).

Even though the tendencies of the graph points out an increase in micro hardness, the standard deviation values of the similar welding couples - T1, T2 and T3 type specimens- indicate that the results were almost overlapped and there was no significant difference due to the homogenous mixture in the welding zone with similar or dissimilar austenitic stainless steels. But the it is more obvious in the tensile strength results that the coherency between filler metal and base metal play a very important role in the final mechanical characteristics of the welding as given in Table 5, the tensile strength of T1 welding couple consisted of AISI 316L stainless steels is much more higher compared to the T2 and T3 ones comprised of AISI 321 and the combination of $316 \mathrm{~L}$ and 321 stainless steels, respectively (13).

The macroscopic images of T1 and T3 type welding couples don't show clearly the start nor the end of the welding seam zone or the heat affected zone (HAZ) as the filler metal has the same composition with one 
or both of the base metal. In Fig. 6 and 8, the welding fusion zones can be described as the non equilibrium but homogenous solidification area as the phase boundaries are not present, but the heat affected seems to get widened due to higher welding current and relatively lower welding speed applied during the process but no granular coarse grains are present, signalling no overheating during the process, on the contrary, in all three types of microstructures the fine-grained zones, sings of high cooling speed are apparent, with also some carbide phase precipitations limiting possible recrystallization of the grains. In Fig. 7, the seam resembling to an arc between the filler and base metal is visible, which is not very clearly caught in macroscopic picture of the T1 type welding couples.

The two essential target of this study to transfer the basic skills to the undergraduate students to roll whole study alone and then to constitute a scientific survey based on their undergraduate thesis study. In the interest of realization of this goal, the investigation of the influence of the welding parameters (shielding gas, welding metals, filler metals, etc.) on the welding of the different types of stainless steels and their combination was prepared. Therefore the results have been ordered as;

- Even the hardness values after welding seem to have tendency to increase, in fact their standard deviations signify almost the same hardness rate for each specimen. However, the tensile strength values point a discrimination between their mechanical properties due to more tough behaviour AISI 316L types welding metals but also the mechanical and chemical coherency of the welding metal and the filler rod.

- The heat affected seems to get widened due to higher welding current and relatively lower welding speed applied during the process but no granular coarse grains are present, signalling no overheating during the process, on the contrary, in all three types of microstructures the finegrained zones, sings of high cooling speed are apparent, with also some carbide phase precipitations limiting possible recrystallization of the grains.

- To acquire more data, the specimens should have been observed using SEM with EDX attachment.

\section{ACKNOWLEDGEMENTS}

We express our gratitude to the enthusiasm for this project and also our beloved professor who passed away this year, Prof. Dr. Ayhan MERGEN. This paper is dedicated in the memory of Prof. Dr. Ayhan MERGEN.

\section{REFERENCES}

[1] D. Ji, S. Lu, W. Dong, D. Li and Y. Li, "Study of the law between the weld pool shape variations with the welding parameters under two TIG processes”, Journal of Materials Processing Technology 212 (2012) 128136.

[2] Q. Li, X. Wang, Z. Zou, J. Wu, "Effect of activating flux on arc shape and arc voltage in tungsten inert gas welding", Trans. Nonferrous Met. Soc. China 17 (2007) 486-490.

[3] A. Kumar, P. Kumar, S. Mishra, R.K. Mishra, T. Srivastav, S. Mishra and R. Kumar, "Experimental Process of Tungsten Inert Gas Welding of A Stainless Steel Plate”, Materials Today: Proceedings 2 (2015) 32603267. 
[4] N. Moslemi, N. Redzuan, N. Ahmad, T. N. Hor, "Effect of Current on Characteristic for 316 Stainless Steel Welded Joint Including Microstructure and Mechanical Properties”, Procedia CIRP 26 (2015) 560-564.

[5] V. A. Rao, R. Deivanathan, "Experimental Investigation for Welding Aspects of Stainless Steel 310 for the Process of TIG Welding", Procedia Engineering 97 (2014) 902-908.

[6] S.A.A. Akbari Mousavi, R. Miresmaeili, "Experimental and numerical analyses of residual stress distributions in TIG welding process for 304L stainless steel.5- S. Zuo, X. Zhou, G. Zhang, "Comprehensive welding technology for type 304 stainless steel rotating shaft”, Procedia Engineering 24 (2011) 840-844.

[7] Topcu, İ., Güllüoğlu, A. N., Bilici, M. K., \& Gülsoy, H. Ö. (2019). Investigation of wear behavior of Ti6Al$4 \mathrm{~V} / \mathrm{CNT}$ composites reinforced with carbon nanotubes. Journal of the Faculty of Engineering and Architecture of Gazi University, 34(3), 1441-1449.

[8] http://www.aksteel.com/pdf/markets_products/stainless/austenitic/321_data_sheet.pdf

[9] Topcu, İ., Gülsoy, H. O., \& Güllüoğlu, A. N. (2019). Evaluation of Multi-Walled CNT particulate reinforced Ti6Al4V alloy based composites creep behavior of materials under static loads. Gazi University Journal of Science, 32(1), 286-298.

[10] S. M. Darwish, A. Al Tamimi and S. Al-Habdan, “A Knowledge Base for Metal Welding Process Selection”, Int. J. Mach. Tools. Manufact. Vol. 37, No. 7, PP. 1007-1023.

[11] Topcu, İ , Karaman, E . (2019). Çok Duvarlı Karbon Nanotüp Takviyeli Düzenli/ Düzensiz Şekilli Ti-6Al4V Kompozitlerin Aşınma Davranışlarının İncelenmesi. Düzce Üniversitesi Bilim ve Teknoloji Dergisi , 7 (3) , 1249-1260 . DOI: 10.29130/dubited.545434

[12] İ.Topcu,(2018),Investigation of Microstructure and Mechanical Properties of Metal Matrix (MMC) Composites Developed with CNT Reinforced Aluminum Matrix Materials,Academic Platform Journal of Engineering and Science6(3),164-167

[13] Topcu, İ, Çınar, Ö, Alyanakoğlu, A, Çetiner, B, Güllüoğlu, A . (2019). The Similar and Dissimilar Spot Welding of 304 and 316L Austenitic Stainless Steels. ALKÜ Fen Bilimleri Dergisi, 1 (2) , 55-59. Retrieved from https://dergipark.org.tr/tr/pub/alku/issue/42573/468394

Geliş/Received: 19 Eyl 2019/19Sep 2019

Kabul Ediliş/Accepted: 07 Oca 2020/07 Jan 2020 